\title{
Article \\ Adaptation of a Bacterial Bioluminescent Assay to Monitor Bioeffects of Gold Nanoparticles
}

\author{
Moustafa R. Yehia ${ }^{1, *}$, Tatyana E. Smolyarova ${ }^{2}$, Alexandr V. Shabanov ${ }^{2}$, Ekaterina S. Sushko ${ }^{2,3}$ (D, \\ Gennady A. Badun ${ }^{4}$ (i) and Nadezhda S. Kudryasheva ${ }^{1,3}$ (D) \\ 1 Biophysics Department, Siberian Federal University, 660041 Krasnoyarsk, Russia; n-qdr@yandex.ru \\ 2 Institute of Physics SB RAS, Federal Research Center 'Krasnoyarsk Science Center SB RAS', \\ 660036 Krasnoyarsk, Russia; smol.nano@yandex.ru (T.E.S.); alexch_syb@mail.ru (A.V.S.); \\ kkovel@yandex.ru (E.S.S.) \\ 3 Institute of Biophysics SB RAS, Federal Research Center 'Krasnoyarsk Science Center SB RAS', \\ 660036 Krasnoyarsk, Russia \\ 4 Department of Chemistry, Moscow State University, 119991 Moscow, Russia; badunga@yandex.ru \\ * Correspondence: moustafa.yehia@city.ac.uk
}

\section{check for}

updates

Citation: Yehia, M.R.;

Smolyarova, T.E.; Shabanov, A.V.;

Sushko, E.S.; Badun, G.A.;

Kudryasheva, N.S. Adaptation of a Bacterial Bioluminescent Assay to

Monitor Bioeffects of Gold

Nanoparticles. Bioengineering 2022, 9,

61. https://doi.org/10.3390/

bioengineering 9020061

Academic Editors: Dang Duong Bang, Sudip K. Das and Ilaria Fratoddi

Received: 4 January 2022

Accepted: 30 January 2022

Published: 3 February 2022

Publisher's Note: MDPI stays neutral with regard to jurisdictional claims in published maps and institutional affiliations.

Copyright: (C) 2022 by the authors. Licensee MDPI, Basel, Switzerland. This article is an open access article distributed under the terms and conditions of the Creative Commons Attribution (CC BY) license (https:// creativecommons.org/licenses/by/ $4.0 /)$.

\begin{abstract}
Our current study aimed to adapt a bioluminescent bacteria-based bioassay to monitor the bioeffects of gold nanoparticles (AuNPs). Luminous marine bacteria Photobacterium phosphoreum and AuNPs modified with polyvinylpyrrolidone were employed; low-concentration $\left(\leq 10^{-3} \mathrm{~g} / \mathrm{L}\right)$ bioeffects of AuNPs were studied. Bioluminescence intensity was used as an indicator of physiological activity in bacteria. Two additional methods were used: reactive oxygen species (ROS) content was estimated with a chemiluminescent luminol method, and bacterial size was monitored using electron microscopy. The bacterial bioluminescent response to AuNPs corresponded to the "hormesis" model and involved time-dependent bioluminescence activation, as well as a pronounced increase in the number of enlarged bacteria. We found negative correlations between the time courses of bioluminescence and the ROS content in bacterial suspensions, demonstrating the relationship between bioluminescence activation and bacterial ROS consumption. The combined effects of AuNPs and a beta-emitting radionuclide, tritium, revealed suppression of bacterial bioluminescent activity (as compared to their individual effects) and a reduced percentage of enlarged bacteria. Therefore, we demonstrated that our bacteria-based bioluminescence assay is an appropriate tool to study the bioeffects of AuNPs; the bioeffects can be further classified within a unified framework for rapid bioassessment.
\end{abstract}

Keywords: gold nanoparticles; luminous marine bacteria; bioassay; hormesis; tritium; reactive oxygen species

\section{Introduction}

It is recognized that materials at the nanoscale possess unique optical, magnetic, catalytic, and electronic properties that differ from those of their bulk form [1-4]. These properties can be exploited to tackle a host of industrial, medical, and research problems. Modern developments in facile and high-yield methods have provided the impetus for an astounding increase in biological applications of nanoparticles (NPs) [5-8]. Whilst a variety of metals, such as silver and copper, are employed in industrial NP applications, gold is clinically utilized for its inert nature, biocompatibility, and propensity for biomolecular ligand immobilization [9-12]. These properties diversify the applicability of gold NPs to include radioprotection, bioimaging, biosensing, and drug delivery. However, this increased use of NPs has been accompanied by inconsistent toxicological studies. An overarching problem in NP toxicity assessment is the variability in protocols used to determine toxicity. These protocols utilize various molecular and chemical techniques, cell lines, and experimental conditions, which result in incomparable toxicity conclusions [13-17]. Consequently, it 
is essential to establish an informative, consistent, and unifying platform for the rapid assessment of nanomaterial effects on biological entities.

An emerging candidate for this unification is a luminous bacterial bioassay. This assay has been extensively employed to monitor sample toxicity in complex media by considering bioluminescence as a physiological testing parameter [18-23]; it enjoys several advantages that include but are not limited to assay simplicity, high sensitivity, high-throughput capacity, and availability of devices for bioluminescence registration. Such advantages allow for large sample analysis and permit in-depth statistical processing, which are essential for investigating low-dose bioeffects of a stochastic nature [23-26]. Bioluminescent assays can operate at several levels of biological organization, either cellular or enzymatic. A classic example is the bioluminescent cellular method based on luminous marine bacteria that has been widely applied since the 1960s [27-31]. The enzymatic bioassay variant was first proposed in 1990 for ecotoxicological monitoring [31]; extensive utilization since the 1980s has highlighted its numerous advantages [32-35]. The primary physicochemical bioluminescent mechanisms and the nature of their interactions in bioluminescent systems have been extensively discussed [36-39]. In our previous works, we exploited the characteristics of bacterial and enzymatic bioluminescent bioassays to investigate the low-dose effects of alpha [40-42], beta [43,44], and gamma radiation [24]. The radioprotective properties of humic substances, products of natural oxidative decomposition of organic compounds in soils, were also demonstrated in solutions of alpha- and beta-emitting radionuclides [45-48]. Our previous works have revealed that bacterial responses to low-dose exogenous compounds correspond to the "hormesis" model [49,50]. This biological response is characterized by three main stages: stress recognition, stimulation, and subsequent inhibition of organism vital functions, i.e., toxicity [51-54].

Recently, we began to use bioluminescence assays to evaluate the bioeffects of nanostructures of natural and artificial origin. We studied NPs with varied core material and surface modification [55-58]. Fullerene derivatives with diverse carbon cage sizes and oxygen substituent amounts, as well as core iron oxides, were under investigation. We compared characteristics of NP bioeffects, such as toxic and antioxidant/pro-oxidant properties. We demonstrated correlations between the characteristics and surface modification, e.g., amount of oxygen substituent in fullerene carbon cages, hydrophobicity of surface modifiers, as well as involvement of exo- or endohedral metal in the fullerene structure. Moreover, we highlighted the involvement of the conjugated $\pi$-system of the carbon cage in fullerenol bioeffects [55]. We further demonstrated an active role of reactive oxygen species (ROS) in the bioeffects of fullerenol NPs [56]; ROS content was monitored using the chemiluminescence luminol method $[59,60]$. This technique determines integral ROS content by assuming a dynamic equilibrium of the different intra- and extracellular ROS. The luminol technique is also highly convenient when tandemly used with bioluminescence measurements, since both techniques use the same instrumentation for the registration of luminescence kinetics. Hence, our previous investigations provided a collection of data that forms a fundamental basis for analyzing and comparing the bioeffects of NPs of different structures (different cores and surface modifications) at cellular and enzymatic levels. We found correlations between structural characteristics and toxic and anti-oxidant effects, which can constitute a predictive tool for appropriate NP selection in pharmacological, biomedical, and ecological applications.

Our current paper focuses on adapting the bacteria-based bioluminescent assay to investigate the bioeffects of gold nanoparticles (AuNPs). AuNPs have been extensively studied and are considered one of the most chemically neutral carriers of bioactive compounds and ligands in targeting local bioprocesses in organisms [61-64]. This study is necessary (1) to provide a consistent comparison of AuNP bioeffects with other nanoparticles and to compare these bioeffects with those of nanostructures previously studied using similar techniques and (2) to develop, through this, a classification of NP bioeffects based on structural characteristics, i.e., core type and surface modification. We plan to expand the number of classified NPs to include AuNPs with distinct surface modifications 
and AuNP nanocomposites. Changes in radiosensitivity of bacteria under exposure to AuNPs and the role of ROS in the molecular mechanisms of AuNP bioeffects are taken into special consideration.

Our study is aimed at:

(a) defining appropriate bioassay conditions (e.g., selection of bacterial growth stage) to study the bioeffects of AuNPs;

(b) investigating the peculiarities of low-concentration effects of AuNPs $\left(10^{-6}-10^{-3} \mathrm{~g} / \mathrm{L}\right)$ on the bioluminescence of marine bacteria;

(c) revealing possible AuNP radioprotective effects in solutions of beta-emitting radionuclide tritium under conditions of low-dose irradiation $(<0.1 \mathrm{~Gy})$;

(d) evaluating the role of ROS in the bioeffects of AuNPs;

(e) elucidating correlations between bacterial cell morphology and bacterial bioluminescence responses in complex AuNP solutions.

AuNPs modified with polyvinylpyrrolidone, a widespread representative of biocompatible AuNPs, were chosen for our experiments.

\section{Materials and Methods}

\subsection{Preparations and Reagents}

Hydrogen tetrachloroaurate(III) trihydrate $\left(\mathrm{HAuCl}_{4} \cdot 3 \mathrm{H}_{2} \mathrm{O}\right)$ was procured from Alfa Aesar (ThermoFisher Inc., Karlsruhe, Germany). Luminol $\left(\mathrm{C}_{8} \mathrm{H}_{7} \mathrm{~N}_{3} \mathrm{O}_{2}\right)$, trisodium citrate $\left(\mathrm{Na}_{3} \mathrm{C}_{6} \mathrm{H}_{5} \mathrm{O}_{7}\right)$, potassium ferricyanide $\left(\mathrm{K}_{3}\left[\mathrm{Fe}(\mathrm{CN})_{6}\right]\right)$, and polyvinylpyrrolidone (PVP) were obtained from Sigma-Aldrich, St. Louis, MO, USA. Tryptone and yeast extract were obtained from Dia-M, Moscow, Russia. Sodium chloride $(\mathrm{NaCl})$, magnesium chloride hexahydrate $\left(\mathrm{MgCl}_{2} 6 \mathrm{H}_{2} \mathrm{O}\right)$, calcium chloride $\left(\mathrm{CaCl}_{2}\right)$, and potassium chloride $(\mathrm{KCl})$ were obtained from Pancreac Applichem ITW Reagents, Germany. Bacterial agar was obtained from Difco Laboratories, Detroit, MI, USA. Potassium hydroxide $(\mathrm{KOH})$ was obtained from Khimreactiv, Nizhny Novgorod, Russia. Tritiated water, HTO, JSC Isotope, Russia, was used as a source of tritium. HTO was added to $\mathrm{NaCl}$ solutions and mixed with the bacterial suspensions to the final specific radioactivities of 2, 10, 50, and $200 \mathrm{MBq} / \mathrm{L}$. All the reagents were of analytical grade and used as received.

\subsection{Bacterial Growth Conditions}

Intact marine luminous bacterium, strain Photobacterium phosphoreum 1883 IBSO [65], was used as a bioassay to evaluate the effects of AuNPs on the bacterial cells. The strain was obtained from the Collection of Luminous Bacteria CCIBSO-863, Institute of Biophysics SB RAS, Krasnoyarsk, Russia. For cultivation of P. phosphoreum, a semisynthetic medium containing $10 \mathrm{~g} / \mathrm{L}$ Tryptone, $28.5 \mathrm{~g} / \mathrm{L} \mathrm{NaCl}, 4.5 \mathrm{~g} / \mathrm{L} \mathrm{MgCl}_{2} \cdot 6 \mathrm{H}_{2} \mathrm{O}, 0.5 \mathrm{~g} / \mathrm{L} \mathrm{CaCl}_{2}, 0.5 \mathrm{~g} / \mathrm{L} \mathrm{KCl}$, $3 \mathrm{~g} / \mathrm{L}$ yeast extract, and $12.5 \mathrm{~g} / \mathrm{L}$ agar was used.

P. phosphoreum was plated on $25 \mathrm{~mL}$ of semisynthetic agar and incubated at $25{ }^{\circ} \mathrm{C}$ for 17 and $24 \mathrm{~h}$ (exponential growth phase and stationary growth phase, respectively) in an incubator (WIS-20R, WiseCube Laboratory Instruments, Wertheim, Germany). Prior to experimentation, bacteria were collected by pipetting of $3 \% \mathrm{NaCl}$ solution directly onto the agar to release bacteria. The bacterial suspension was then diluted to an optical density $=0.1$ at $660 \mathrm{~nm}$ and stored at $4{ }^{\circ} \mathrm{C}$ for $30 \mathrm{~min}$ to allow bioluminescence stabilization prior to experimentation. The $\mathrm{NaCl}$ was of analytical grade. The $3 \% \mathrm{NaCl}$ solutions were used to mimic a marine environment for the bacterial cells and to maintain osmotic processes.

\subsection{Preparation and Characterization of Gold Nanoparticles}

AuNPs modified with PVP were prepared according to the sodium citrate reduction method [66]. Briefly, $5 \mathrm{~mL}$ of $0.1 \mathrm{mM}$ sodium tricitrate solution was added to a $100 \mathrm{~mL}$ boiling solution of $0.5 \mathrm{mM} \mathrm{HAuCl}_{4}$, and the reaction was allowed to react for $30 \mathrm{~min}$ under continuous stirring. The sodium citrate nanoparticle solution was then allowed to stabilize for $24 \mathrm{~h}$ prior to ligand replacement. The resulting nanoparticle solution was resuspended in ethanol for ligand replacement. Subsequently, $5 \mathrm{~mL}$ of polyvinylpyrroli- 
done (PVP) aqueous solution (60 PVP molecules per $\mathrm{nm}^{2}$ of nanoparticle) was added to the sodium citrate nanoparticles and allowed to react overnight under continuous stirring. The final solution was centrifuged at 4000 RPM to remove impurities and unreacted reagents and redispersed in distilled water. Transmission electron microscopy (TEM) images and dynamic light scattering (DLS) confirmed the presence of spherical $15 \mathrm{~nm}$ AuNPs (Figure S1B,D in Supplementary Materials, respectively). Additionally, AuNP aggregate clusters appeared (post ligand replacement) and were also visualized microscopically (Figure S1A in Supplementary Materials). The size distribution of bare AuNPs (sharp peak at $\sim 15 \mathrm{~nm}$ ) and aggregated (broadened peak at $\sim 80 \mathrm{~nm}$ ) AuNPs in solution was further visualized by TEM size distribution (Figure S1C in Supplementary Materials).

\subsection{Luminescence Measurements}

\subsubsection{Bioluminescence Assay Samples}

Bioluminescence kinetics was studied in the bacterial suspensions of different compositions: bacteria (control samples); bacteria + AuNPs; bacteria + HTO; bacteria + HTO + AuNPs. The bacterial suspensions were prepared as follows. Control samples: $400 \mu \mathrm{L}$ of non-radioactive bacteria suspensions was added to $1600 \mu \mathrm{L}$ of $3 \% \mathrm{NaCl}$ solution. Samples (bacteria + AuNPs): $400 \mu \mathrm{L}$ of bacterial suspensions and $400 \mu \mathrm{L}$ of AuNPs were added to $1200 \mu \mathrm{L}$ of $3 \% \mathrm{NaCl}$ solution. Radioactive samples (bacteria $+\mathrm{HTO}$ ): $400 \mu \mathrm{L}$ of bacterial suspensions was added to $50 \mu \mathrm{L}$ of $\mathrm{HTO}$ in $1550 \mu \mathrm{L}$ of $3 \% \mathrm{NaCl}$ solution. Radioactive samples (bacteria + HTO + AuNPs): $400 \mu \mathrm{L}$ of bacterial suspensions and $400 \mu \mathrm{L}$ of AuNPs were added to $50 \mu \mathrm{L}$ of $\mathrm{HTO}$ in $1150 \mu \mathrm{L}$ of $3 \% \mathrm{NaCl}$ solution.

\subsubsection{Bioluminescence Registration}

To investigate the chronic effects of AuNPs on the bacterial cells, standard procedures for bioluminescence measurements were used [26,65]. Bioluminescence intensity time courses were measured for $21 \mathrm{~h}$. The relative bioluminescence intensities, $I^{\text {rel }}$, were calculated as ratios of the bioluminescence intensities of experimental and control suspensions. The time courses of $I^{r e l}$ were studied at different concentrations of AuNPs and HTO and their combinations (see Section 2.4.1). The radioactive dose accumulated in the bacterial samples did not exceed 0.1 Gy. Optical density of AuNP solutions did not exceed 0.1 in maxima of the bioluminescence and chemiluminescence light emittance- 490 and $425 \mathrm{~nm}$, respectively; hence, the effect of "optic filter" was excluded [67]. All measurements were carried out in 5-10 replicates; error did not exceed 10\%.

\subsubsection{Chemiluminescence Assay for Evaluation of Reactive Oxygen Species Content}

We used the luminol chemiluminescence method $[59,60]$ to evaluate the content of reactive oxygen species (ROS) in the experimental bacterial suspensions. Chemiluminescence registration was carried out just after the bioluminescence measurements in the same bacterial samples. The calibration dependence was preliminarily determined as chemiluminescence intensity vs. $\mathrm{H}_{2} \mathrm{O}_{2}$ concentration; $\mathrm{H}_{2} \mathrm{O}_{2}$ was considered a representative of the ROS family. Concentrations of alkaline luminol and $\mathrm{K}_{3}\left[\mathrm{Fe}(\mathrm{CN})_{6}\right]$ solutions were $5 \times 10^{-4} \mathrm{M}$ and $5 \times 10^{-3} \mathrm{M}$, respectively. Calibration dependency is presented in Figure S2 in Supplementary Materials.

ROS content was evaluated in bacterial suspensions in $3 \% \mathrm{NaCl}$ solutions at different concentrations of AuNPs $\left(10^{-6}-10^{-3} \mathrm{~g} / \mathrm{L}\right), \mathrm{HTO}(2,10,200 \mathrm{MBq} / \mathrm{L})$ and their combinations at various times of exposure. Maximal chemiluminescence intensity was determined in bacterial suspensions after bioluminescence measurements. To provide this, the luminol solutions were added to the bacterial samples. Then, the chemiluminescence reaction was initiated by $75 \mu \mathrm{L}$ solution of $\mathrm{K}_{3}\left[\mathrm{Fe}(\mathrm{CN})_{6}\right](\mathrm{pH} 11.24)$ through the injection system. Chemiluminescence intensity was used to calculate ROS content in the experimental solutions via the calibration dependence (Figure S2 in Supplementary Materials). Relative values of ROS content, ROS ${ }^{\text {rel }}$, were calculated as ratios of ROS content in experimental 
and control solutions; kinetics of $R O S^{r e l}$ were plotted. All measurements were carried out in 5 replicates; error did not exceed $10 \%$.

\subsection{Microscopy}

Samples for electron microscopy were prepared identically to those described in Section 2.4.1: control bacteria; bacteria + AuNPs; bacteria + HTO; bacteria + HTO + AuNPs. All samples were allowed to react for $3 \mathrm{~h}$ prior to fixation. Afterwards, the samples were initially mixed with $2 \%$ formaldehyde solution $(1: 1 \mathrm{v} / \mathrm{v})$ for $1 \mathrm{~h}$ prior to deposition on the absorbing matrix and allowed to air dry for 15 min prior to imaging. Microscopy settings and sample preparation were replicated according to a method developed for biological object fixation on inverse opals, as previously described in [68]. Briefly, silica inverse opals were prepared by a sol-gel method to study biological objects. Submicron spherical particles were obtained from polymethylmethacrylate to produce 100 to $500 \mathrm{~nm}$ particles that were ordered into an inverse opal crystal matrix. This created an open system of pores up to $400 \mathrm{~nm}$ in size that was used for sample adsorption.

\subsection{Equipment}

Time courses of luminescence intensity were registered by Luminoskan Ascent (Thermo Fisher 219 Corp., Waltham, MA, USA). Optical density and absorbance of the bacterial and nanoparticle solutions were measured by an UVIKON-943 double-beam spectrophotometer (KONTRON Instruments, Milano, Italy). All luminescence measurements were carried out at $+20^{\circ} \mathrm{C}$. An SU3500 SEM (Hitachi, Tokyo, Japan) was used for bacterial morphological analysis. AuNP shape and size were determined by transmission electron microscopy (TEM) (Hitachi S-5500) and Zetasizer (Malvern instruments, Malvern, UK), respectively.

\subsection{Statistical Processing}

To evaluate correlations between time courses of bioluminescence intensity and ROS content ( $I^{r e l}$ and $R O S^{r e l}$, respectively), a statistical dependence between the rankings of the two variables was analyzed [69], and Spearman's rank correlation coefficients ( $r$ ) were calculated. The application of this method was justified with a moderate kit of data sets, as well as a lack of normal distribution of $I^{r e l}$ and $R O S^{r e l}$.

\section{Results and Discussion}

\subsection{Bacterial Growth Phase Selection}

We chose spherical AuNPs (15 nm) functionalized with polyvinylpyrrolidone (PVP) as representatives of biocompatible nanoparticles. Our preliminary adaptation of the bioluminescence assay involved the choice of bacterial growth stage (exponential or stationary) for AuNP bioeffect assessment. Conventionally, most toxicity assays employing bacterial bioluminescence select bacteria from the exponential growth phase $(17 \mathrm{~h})$ due to maximal luminescence and sensitivity [70,71]. We sampled bacteria from both the exponential and stationary growth phases (17 and $24 \mathrm{~h}$, respectively) and exposed them to four concentrations of AuNPs $\left(10^{-3}, 10^{-4}, 10^{-5}, 10^{-6} \mathrm{~g} / \mathrm{L}\right)$. The bacteria sampled at the exponential stage of growth $(17 \mathrm{~h})$ did not show distinct differences at various concentrations of AuNPs (Figure S3 in Supplementary Materials). However, the bioluminescent kinetics of the bacteria sampled from the stationary growth phase $(24 \mathrm{~h})$ demonstrated considerable deviations from the control (Figure 1A), indicating suitability for studying AuNP bioeffects under low-concentration conditions. While the deviations (Figure 1A) may seem stochastic, they are particularly valuable when considered through the hormesis model, which supposes a nonlinear dependency of bioeffects on dosage (Figure 1B). 


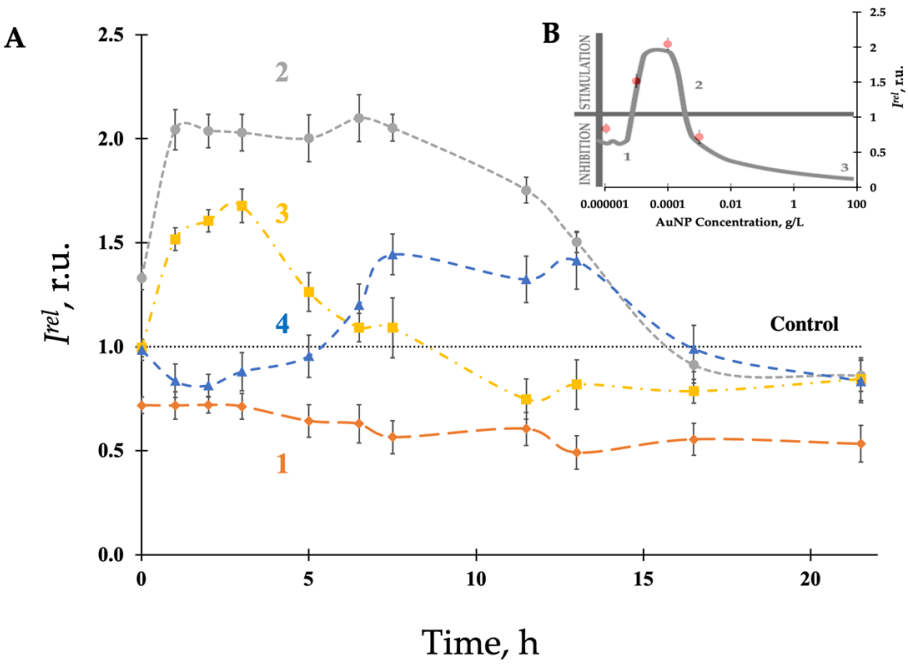

Figure 1. Bioluminescence intensity of bacteria, $I^{r e l}$, sampled at stationary growth phase $(24 \mathrm{~h})$. (A) Bioluminescence kinetics after exposure to AuNPs of different concentrations (color curves): $10^{-3} \mathrm{~g} / \mathrm{L}(\mathbf{1}), 10^{-4} \mathrm{~g} / \mathrm{L}(2), 10^{-5} \mathrm{~g} / \mathrm{L}(3)$, and $10^{-6} \mathrm{~g} / \mathrm{L}$ (4); (B) Bioluminescence intensity, I ${ }^{\text {rel }}$, at different concentrations of AuNPs (red points), 3-h exposure. Hormetic curve (gray color) is presented according to descriptions presented in [46]. Three stages of hormesis include: (1) stress recognition, (2) physiological activation, (3) inhibition of vital functions.

Figure 1B presents bioluminescence intensity, $I^{\text {rel }}$, at four concentrations of AuNPs after $3 \mathrm{~h}$ exposure (red points). We observed a similar tendency at various other exposure times and AuNP concentrations. As seen from this figure, the nonlinear concentration dependence is consistent with the classic hormetic curve described in previous works on the hormesis phenomenon [72-75]. We can observe that AuNP concentrations approximately fall within the three classical stages of hormesis: stress recognition, physiological activation, and inhibition of vital functions. As a phenomenon, hormesis involves favorable biological responses to low exposures of stressors (e.g., chemical or radiation) [70]. In toxicology, hormesis is a dose-response phenomenon characterized by low-dose physiological stimulation and higher-dose inhibition, resulting in classical J-shaped or inverted U-shaped curves. This phenomenon is highly generalizable and independent of biological model, endpoint selection, stressor type, and biological level of organization (enzymatic, cellular, or whole organism). Nevertheless, although hormesis has been extensively studied in the past few decades, the hormesis mechanisms remain elusive. Therefore, experimental studies elucidating molecular mechanisms of hormesis responses, particularly in bacterial cells, are of significant interest.

Hence, our current experiment revealed that the resultant bioeffect of AuNPs is concentration-dependent only for bacteria sampled at the stationary growth phase ( $24 \mathrm{~h})$. We speculate that our results are due to differences in membrane composition between exponential and stationary phase bacteria. Given these results, we chose bacteria from the stationary growth phase for further experiments.

\subsection{Combined Effects of AuNPs and Tritium on Luminescent Bacteria}

To investigate the influence of low-intensity radioactive exposure, we used tritium, a low-energy (18.575 keV), beta-emitting radionuclide, applied as a component of tritiated water (HTO). The effects of tritium on luminous marine bacteria were previously studied in detail $[24,26,38,43,44]$. These studies showed that bioluminescence kinetic curves involved activation $\left(I^{\text {rel }}>1\right)$ and inhibition $\left(I^{\text {rel }}<1\right)$ stages and were described in terms of hormesis phenomena. Our current study similarly demonstrated a hormetic dependence with moderate bioluminescence inhibition and activation in response to $\mathrm{HTO}(2 \mathrm{MBq} / \mathrm{L})$ exposure (Figure 2A-C, curve 1). 

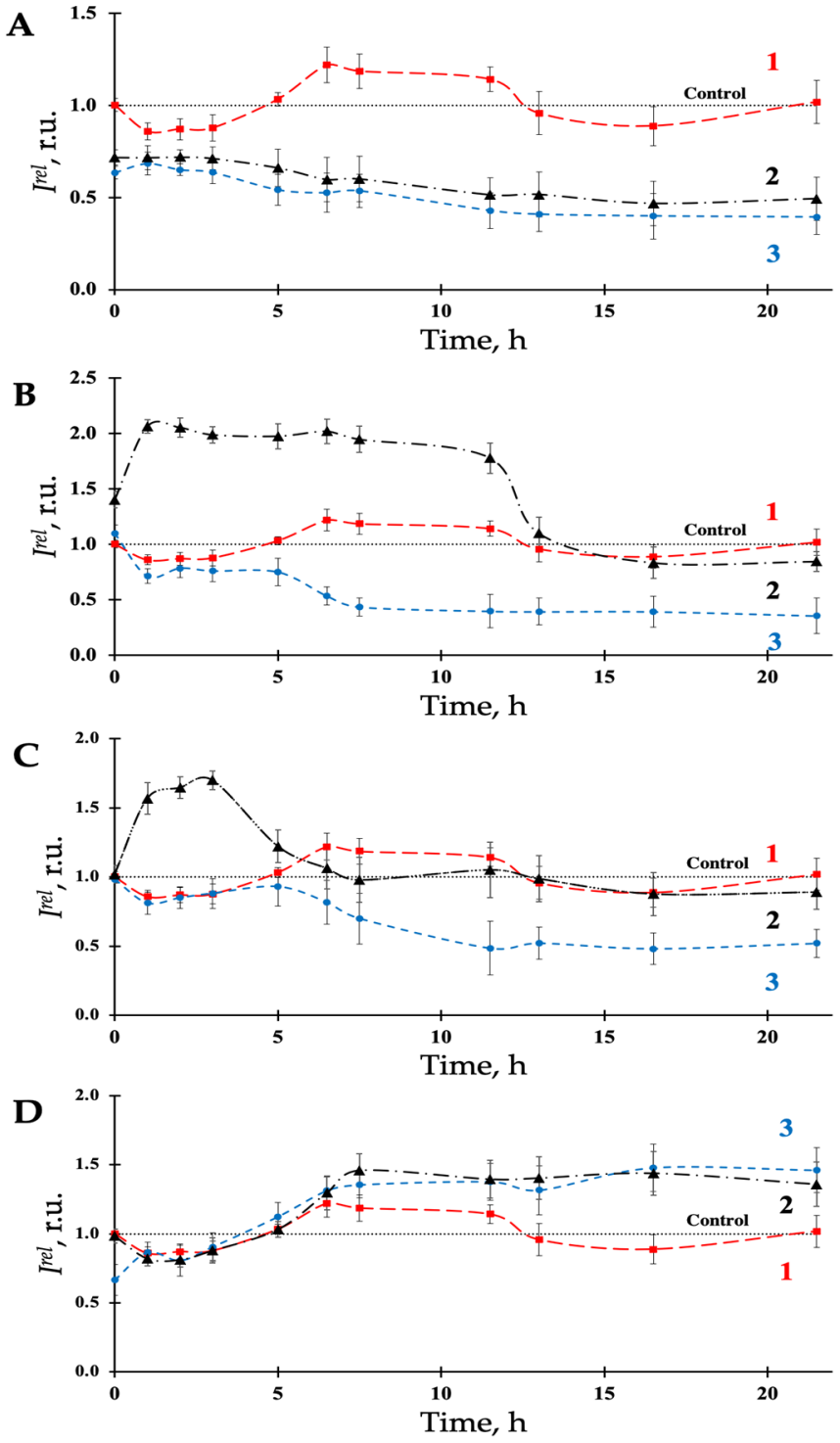

Figure 2. Bioluminescence intensity, $I^{\text {rel }}$, in bacterial suspensions in the presence of HTO (2 MBq/L) and/or AuNPs of different concentrations (colored curves): (1) HTO, (2) AuNPs, AuNPs + HTO, (3) $2 \mathrm{MBq} / \mathrm{L}$. Concentrations of AuNPs: (A) $-10^{-3} \mathrm{~g} / \mathrm{L},(\mathbf{B})-10^{-4} \mathrm{~g} / \mathrm{L},(\mathbf{C})-10^{-5} \mathrm{~g} / \mathrm{L}$, (D) $-10^{-6} \mathrm{~g} /$ L.3.3. Effects of AuNPs on Bacterial Bioluminescence and ROS Content.

Figure 2 highlights the individual and combined effects of HTO and AuNPs on bacterial luminescence. Several concentrations of AuNPs were applied (Figure 2A-D). We can observe that AuNPs and HTO independently produce bioluminescent activation (curves 1 and 2). However, combinations of AuNPs and HTO produce consistent bioluminescence inhibition (curve 3), excluding the lowest concentration of AuNPs (Figure 2D). Non-additivity of effects of AuNPs and HTO in complex solutions of AuNPs + HTO is apparent from the comparison of kinetic curves 1, 2, and 3 in Figure 2A-D. This may allude to complex interactions of the solution components, which plausibly involve intercomponent and bacteria-component interactions. Our results confirmed the radiosensitizing capacity of AuNPs towards bacterial cells in solutions of beta-emitting radionuclide tritium. In biomedical applications, radiosensitization is a physical or chemical method used to amplify the deleterious effects of radiation exposure [76]. The clinical use of materials with radiosensitizing properties has brought significant attention to metal-based nanoparticle radiosensitization $[77,78]$. Despite the radiosensitizing capacity of AuNPs having been demonstrated, the underlying mechanism remains significantly debated [79]. 
Physicochemical mechanisms of biological activation by biocompatible AuNPs are of particular interest. We studied the role of ROS in AuNP bioeffects on bacterial cells in additional bioluminescence and chemiluminescence experiments. The time courses of bioluminescence, $I^{\text {rel }}$, (curve 1) and ROS content, ROS $^{\text {rel }}$, (curve 2) in bacterial suspensions with different concentrations of AuNPs $\left(10^{-3}, 10^{-4}\right.$, and $\left.10^{-5} \mathrm{~g} / \mathrm{L}\right)$ are presented in Figure 3A-C. A moderate increase in bioluminescence $\left(I^{r e l}>1\right)$ was observed with exposure to AuNPs at all three concentrations for most of the duration of bioluminescence monitoring (Figure 3A-C, curve 1). Inversely, corresponding decreases in ROS content $\left(\right.$ ROS $\left.^{\text {rel }}<1\right)$ were observed (curve 2$)$. High negative correlation coefficients, $r$, between the time courses of $I^{\text {rel }}$ and $R O S^{\text {rel }}$ were found: A: -0.9 ; B: -0.7 : C: -0.9 , for Figure 3A-C, respectively $(p<0.05)$. These results corroborate our previous studies, wherein analogous negative correlations were found under exposure to radioactivity as a biological stressor [46]. We may conclude that low concentrations of AuNPs simultaneously intensify bioluminescence activation and ROS consumption. Biological regulation of ROS by AuNPs may involve the formation of weak hydroxyl bonds with adjacent water molecules, leading to lower ionization energy of surrounding media, as discussed in [80-84]. Further studies are required to elucidate the connection between ROS regulation and bioluminescence intensification.
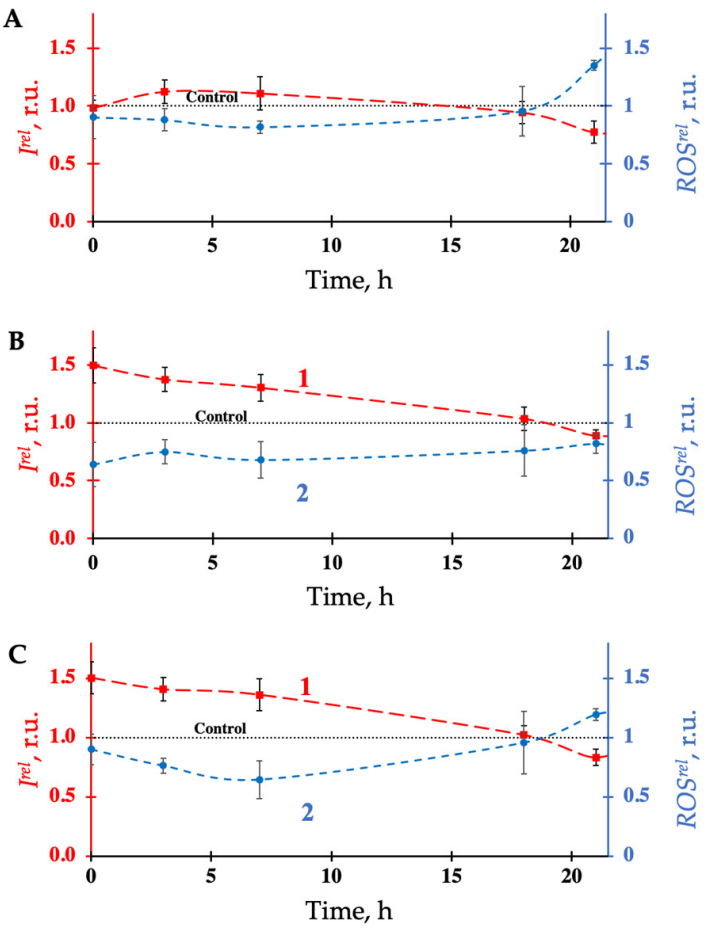

Figure 3. Kinetics of bacterial bioluminescent intensity, $I^{\text {rel }},(\mathbf{1})$ (red color) and relative ROS content, ROS $^{\text {rel }}$, (2) (blue color) in the presence of AuNPs of different concentrations: (A)-10 $-3 \mathrm{~g} / \mathrm{L}$; (B) $-10^{-4} \mathrm{~g} / \mathrm{L}$; (C) $-10^{-5} \mathrm{~g} / \mathrm{L}$. The ROS content in the control (non-radioactive) bacterial suspension decayed from $5.9 \times 10^{-6} \mathrm{M}$ to $1.7 \times 10^{-6} \mathrm{M}$ during the duration of the experiments.

\subsection{Morphology of Bacterial Cells Exposed to AuNPs}

We aimed to elucidate whether changes in cellular morphology correlated with bioluminescence activation or inhibition. Specifically, we utilized microscopy imaging to study bacterial cell morphology in four samples: (1) control bacteria; (2) bacteria + AuNPs; (3) bacteria + HTO; (4) bacteria + HTO + AuNPs:

(1) Control bacteria had average sizes between 0.5 and $2.5 \mu \mathrm{m}$, with uniform thickness and normally distributed sizes. Significantly large $(>4 \mu \mathrm{m})$ and elongated bacteria constituted $7 \%$ of all cells. 
(2) After exposing the bacteria to AuNPs, $10^{-3} \mathrm{~g} / \mathrm{L}$, we observed a change in the size distribution relative to the control; significantly large $(>4 \mu \mathrm{m})$ and elongated bacteria constituted a larger percentage of the size distribution (27\%) (Figure 4). The increase in bacterial size was accompanied by noticeable changes in bioluminescence intensity under AuNP exposure, as discussed previously (curve 1 in Figure 3A-C). Conceivably, exposure to AuNPs modified with PVP may have influenced bacterial growth cycles, as with other biocompatible surface ligands seen in [85]. This is supported by reports of biocompatible AuNPs intensifying cell division and increasing bacterial cell size in Gram-negative bacteria [86]. These results warrant further studies regarding the effects of AuNP exposure on bioluminescence dynamics and cellular morphology.

(3) Exposure to $\mathrm{HTO}, 50 \mathrm{MBq} / \mathrm{L}$, revealed $16 \%$ significantly large $(>4 \mu \mathrm{m})$ and elongated bacteria. Hence, we observed a moderate effect of HTO on cell length, particularly through abnormal elongation of cells. This moderate increase in bacterial size was accompanied by moderate bioluminescence activation under HTO exposure (curve 1, Figure 2A-D). We should note that the damaging effect of tritium (100 MBq/L) on the ultrastructure of lyophilized luminescent bacteria was observed previously [43]; however, the conditions of our current experiment did not reveal any structurally damaging effects, likely due to the use of intact bacteria and lower exposure times.

(4) Finally, we studied the combined effects of AuNPs and $\mathrm{HTO}, 10^{-3} \mathrm{~g} / \mathrm{L}$ and $50 \mathrm{MBq} / \mathrm{L}$, respectively. We observed a bacterial size distribution similar to HTO alone (15\%). Nevertheless, unlike HTO alone, we observed abnormally elongated bacterial cells identical to those seen under AuNP exposure. Altogether, we observed a nonadditive inhibitory effect of $\mathrm{HTO}+$ AuNP on luminous marine bacteria, demonstrated in Figure $2 \mathrm{~A}-\mathrm{C}$, (curves 3 ), accompanied by a decrease in the amount (up to $15 \%$ ) of significantly large $(>4 \mathrm{~mm}$ ) and elongated bacteria, as compared to the effect of AuNPs alone (27\%). These changes should be further investigated under the hypothesis of media ionization and intensification of membrane processes by HTO in bioluminescence activation [44].
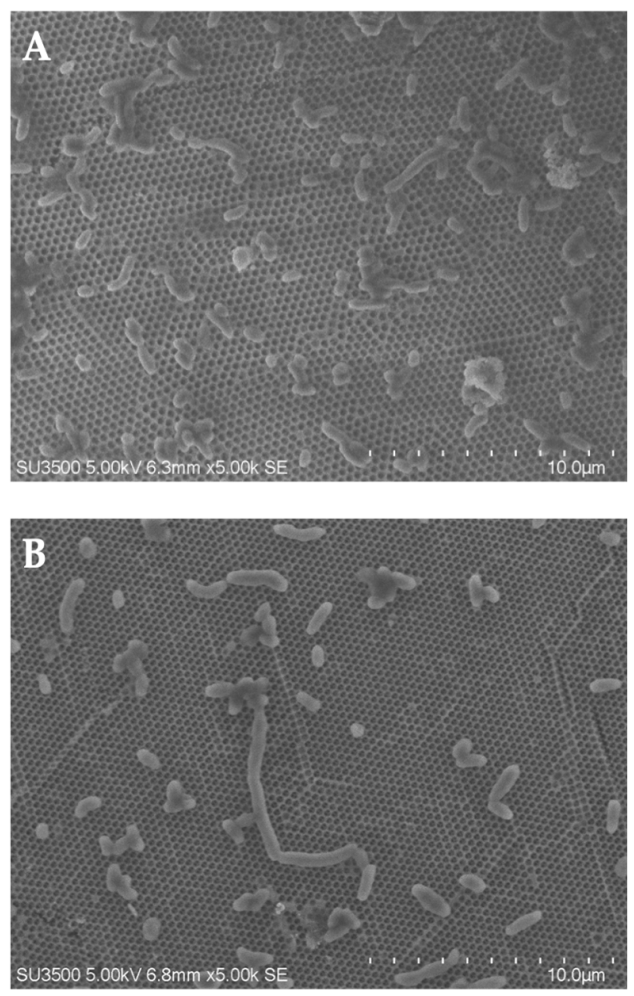

Figure 4. Scanning electron microscopy images of P. phosphoreum after 3 h. (A): control. (B): AuNPs $\left(10^{-3} \mathrm{~g} / \mathrm{L}\right)$. 


\section{Conclusions}

At present, the biological effects of nanostructures are of significant interest to diverse fields of biomedicine and environmental technologies. The modifiability of nanoparticle surfaces diversifies their interactions with surrounding media and organisms. This complexity prevents the prediction of nanoparticle bioeffects based solely on physicochemical characteristics; integral and nonspecific biological assessment methods should be involved. Bioluminescent bioassays are prospective candidates for the comparison of the biological activity of various nanoparticles due to their simplicity and high-throughput capacity.

In recent years, we have studied and compared the toxic and antioxidant properties of nanostructures with diverse cores (iron oxides and carbon) and ligands, as well as bioactive macromolecules of natural origin, i.e., humic substances. Our current study aimed to complement the series of studied nanostructures with AuNPs, which have been subject to extensive investigation and application, primarily due to their biologically inert nature. This study contributes to nanoparticle bioactivity classification per structural characteristics, which we aim to develop extensively. Based on recent advances in biogenic nanoparticle synthesis and characterization, we aim to utilize our method to further investigate the toxic profiles and applications of biogenic nanoparticles with varying core compositions and surface ligands [87-91]. We hope that the recent preponderance of data on biogenic nanoparticles can contribute to the elucidation of the mechanisms of nanoparticle toxicity and hormesis.

Our current paper showed that luminous marine bacteria P. phosphoreum sampled at the stationary growth phase (in contrast to the exponential growth stage) are more sensitive to low-concentration suspensions of AuNPs $\left(<10^{-3} \mathrm{~g} / \mathrm{L}\right)$ and can hence be preferentially applied in a bioluminescent assay to monitor AuNP bioeffects. We chose AuNPs modified with polyvinylpyrrolidone due to their extensive use in research and industrial applications. The bacterial response to AuNP exposure corresponded to the "hormesis" model and involved dose-dependent activation and inhibition of bioluminescence, in addition to increased bacterial size. We found negative correlations between the time courses of bioluminescence and ROS content in bacterial suspensions, demonstrating that bacterial bioluminescence activation by AuNPs is concerned with ROS consumption by bacteria. The combined exposure to AuNPs and a beta-emitting radionuclide tritium revealed a suppression of bacterial bioluminescence (in contrast to the individual effects of AuNPs and tritium) and a reduced percentage of enlarged bacteria. Thus, we have demonstrated that our bacteria-based bioluminescence assay exhibits strong potential as an appropriate tool for studying and comparing the bioeffects of AuNPs and other bioactive nanocompounds. Additionally, we have demonstrated the potential of coupling our bioluminescent assay with other research methods that include microscopic and spectroscopic techniques to achieve a more nuanced understanding of nanomaterial toxicity profiles.

Supplementary Materials: The following supporting information can be downloaded at: https: / / www.mdpi.com/article/10.3390/bioengineering9020061/s1, Figure S1: Characterization of AuNPs by transmission electron microscopy (TEM) and dynamic light scattering (DLS). Figure S2: Calibration curve for chemiluminescence luminol method for ROS evaluation. Dependence of chemiluminescence intensity on concentration of $\mathrm{H}_{2} \mathrm{O}_{2}$. Figure S3: Bioluminescence kinetics of bacteria sampled at exponential phase of growth $(17 \mathrm{~h})$ in the presence of AuNPs.

Author Contributions: Conceptualization, M.R.Y. and N.S.K.; methodology, M.R.Y., A.V.S., E.S.S., G.A.B. and T.E.S.; validation, N.S.K.; investigation, M.R.Y., A.V.S., T.E.S., G.A.B. and N.S.K.; data curation, M.R.Y., E.S.S. and A.V.S.; writing-original draft preparation, M.R.Y. and N.S.K.; writingreview and editing, M.R.Y., A.V.S. and N.S.K.; visualization, M.R.Y. and N.S.K. All authors have read and agreed to the published version of the manuscript.

Funding: This research was funded by RFBR, N18-29-19003; RFBR, Krasnoyarsk Territory and Krasnoyarsk Regional Fund of Science, N20-44-243001; and partly supported by the Program of the Federal Service for Surveillance on Consumer Rights Protection and Human Wellbeing, Fundamental Study 2020-2025 (Russian Federation). 
Institutional Review Board Statement: Not applicable.

Informed Consent Statement: Not applicable.

Data Availability Statement: Not applicable.

Acknowledgments: We acknowledge Olga Mogil'naya for her expertise and assistance in microscopy image analysis.

Conflicts of Interest: The authors declare no conflict of interest.

\section{References}

1. Gold, K.; Buford, S.; Knackstedt, M.; Gaharwar, A. Antimicrobial Activity of Metal and Metal-Oxide Based Nanoparticles. Adv. Ther. 2018, 1, 1700033. [CrossRef]

2. Kong, F.Y.; Zhang, J.W.; Li, R.F.; Wang, Z.X.; Wang, W.J.; Wang, W. Unique Roles of Gold Nanoparticles in Drug Delivery, Targeting and Imaging Applications. Molecules 2017, 22, 1445. [CrossRef] [PubMed]

3. Gupta, R.; Xie, H. Nanoparticles in Daily Life: Applications, Toxicity and Regulations. J. Environ. Pathol. Toxicol. Oncol. 2018, 37, 209-230. [CrossRef] [PubMed]

4. Verma, M.L.; Kumar, P.; Sharma, S.; Dhiman, K.; Sharma, D.; Verma, A. Gold Nanoparticle-Mediated Delivery of Therapeutic Enzymes for Biomedical Applications. Nanosci. Med. 2020, 1, 89-115. [CrossRef]

5. Mosa, K.A.; El-Naggar, M.; Ramamoorthy, K.; Alawadhi, H.; Elnaggar, A.; Wartanian, S.; Ibrahim, E.; Hani, H. Copper Nanoparticles Induced Genotoxicty, Oxidative Stress, and Changes in Superoxide Dismutase (SOD) Gene Expression in Cucumber (Cucumis sativus) Plants. Front. Plant Sci. 2018, 9, 872. [CrossRef] [PubMed]

6. Sengul, A.B.; Asmatulu, E. Toxicity of metal and metal oxide nanoparticles: A review. Environ. Chem. Lett. 2020, 18, 1659-1683. [CrossRef]

7. Repenko, T.; Rix, A.; Nedilko, A.; Rose, J.; Hermann, A.; Vinokur, R.; Moli, S.; Cao-Milàn, R.; Mayer, M.; von Plessen, G.; et al. Strong Photoacoustic Signal Enhancement by Coating Gold Nanoparticles with Melanin for Biomedical Imaging. Adv. Funct. Mater. 2018, 28, 1705607. [CrossRef]

8. Dong, Y.C.; Hajfathalian, M.; Maidment, P.S.N. Effect of Gold Nanoparticle Size on Their Properties as Contrast Agents for Computed Tomography. Sci. Rep. 2019, 9, 14912. [CrossRef]

9. Ou, J.; Liu, K.; Jiang, J.; Wilson, D.A.; Liu, L.; Wang, F.; Wang, S.; Tu, Y.; Peng, F. Micro-/Nanomotors toward Biomedical Applications: The Recent Progress in Biocompatibility. Small 2020, 16, 1906184. [CrossRef]

10. Slesiona, N.; Thamm, S.; Stolle, H.L.K.S.; Weißenborn, V.; Müller, P.; Csáki, A.; Fritzsche, W. DNA-Biofunctionalization of CTAC-Capped Gold Nanocubes. Nanomaterials 2020, 10, 1119. [CrossRef]

11. Sun, H.; Jia, J.; Jiang, C.; Zhai, S. Gold Nanoparticle-Induced Cell Death and Potential Applications in Nanomedicine. Int. J. Mol. Sci. 2018, 19, 754. [CrossRef] [PubMed]

12. Ali, M.R.; Wu, Y.; El-sayed, M.A. Gold-Nanoparticle-Assisted Plasmonic Photothermal Therapy Advances Toward Clinical Application. J. Phys. Chem. 2019, 123, 15375-15393. [CrossRef]

13. Schmid, G.; Kreyling, W.G.; Simon, U. Toxic effects and biodistribution of ultrasmall gold nanoparticles. Arch. Toxicol. 2017, 91, 3011-3037. [CrossRef]

14. Tao, C. Antimicrobial activity and toxicity of gold nanoparticles: Research progress, challenges and prospects. Lett. Appl. Microbiol. 2018, 67, 537-543. [CrossRef] [PubMed]

15. Carnovale, C.; Bryant, G.; Shukla, R.; Bansal, V. Identifying Trends in Gold Nanoparticle Toxicity and Uptake: Size, Shape, Capping Ligand, and Biological Corona. ACS Omega 2019, 4, 242-256. [CrossRef]

16. Elahi, N.; Kamali, M.; Baghersad, M.H. Recent biomedical applications of gold nanoparticles: A review. Talanta 2018, 184, 537-556. [CrossRef]

17. Libralato, G.; Galdiero, E.; Falanga, A.; Carotenuto, R.; De Alteriis, E.; Guida, M. Toxicity Effects of Functionalized Quantum Dots, Gold and Polystyrene Nanoparticles on Target Aquatic Biological Models: A Review. Molecules 2017, 22, 1439. [CrossRef]

18. Muneeswaran, T.; Kalyanaraman, N.; Vennila, T. Rapid assessment of heavy metal toxicity using bioluminescent bacteria Photobacterium leiognathi strain GoMGm1. Environ Monit Assess 2021, 193, 109. [CrossRef]

19. Esimbekova, E.N.; Nemtseva, E.V.; Bezrukikh, A.E.; Jukova, G.V.; Lisitsa, A.E.; Lonshakova-Mukina, V.I.; Rimatskaya, N.V.; Sutormin, O.S.; Kratasyuk, V.A. Bioluminescent enzyme inhibition-based assay to predict the potential toxicity of carbon nanomaterials. Toxicol. In Vitr. 2017, 45, 128-133. [CrossRef]

20. Fleiss, A.; Sarkisyan, K.S. A brief review of bioluminescent systems. Curr. Genet. 2019, 65, 877-882. [CrossRef]

21. Ismailov, A.D.; Aleskerova, L.E. Photobiosensors Containing Luminescent Bacteria. Biochemistry 2015, 80, 733-744. [CrossRef] [PubMed]

22. Abbas, M.; Adil, M.; Ehtisham-ul-Haque, S.; Munir, B.; Yameen, M.; Ghaffar, A.; Shar, G.A.; Asif Tahir, M.; Iqbal, M. Vibrio Fischeri Bioluminescence Inhibition Assay for Ecotoxicity Assessment: A Review. Sci. Total Environ. 2018, 626, 1295-1309. [CrossRef] [PubMed]

23. Kudryasheva, N.S.; Kovel, E.S. Monitoring of Low-intensity Exposures via Luminescent Bioassays of Different Complexity: Cells, Enzyme Reactions and Fluorescent Proteins. Int. J. Mol. Sci. 2019, 20, 4451. [CrossRef] [PubMed] 
24. Kudryasheva, N.S.; Petrova, A.S.; Dementyev, D.V.; Bondar, A.A. Exposure of Luminous Marine Bacteria to Low-Dose GammaRadiation. J. Environ. Radioact. 2017, 169-170, 64-69. [CrossRef] [PubMed]

25. Rozhko, T.V.; Nogovitsyna, E.I.; Badun, G.A.; Lukyanchuk, A.N.; Kudryasheva, N.S. Reactive Oxygen Species and Low-Dose Effects of Tritium on Bacterial Cells. J. Environ. Radioact. 2019, 208-209, 1-5. [CrossRef] [PubMed]

26. Yamauchi, M.; Sakuma, S. Development of Bioassay System for Evaluation of Materials for Personal Protective Equipment (PPE) against Toxic Effects of Ionizing Radiations. Ind. Health 2017, 55, 580-583. [CrossRef] [PubMed]

27. Bulich, A.A.; Isenberg, D.L. Use of the Luminescent Bacterial System for the Rapid Assessment of Aquatic Toxicity. ISA Trans. 1981, 20, 29-33. [PubMed]

28. Girotti, S.; Ferri, E.N.; Fumo, M.G.; Maiolini, E. Monitoring of Environmental Pollutants by Bioluminescent Bacteria. Anal. Chim. Acta 2008, 608, 2-29. [CrossRef]

29. Roda, A.; Guardigli, M.; Michelini, E.; Mirasoli, M. Bioluminescence in Analytical Chemistry and in Vivo Imaging. TrAC-Trends Anal. Chem. 2009, 28, 307-322. [CrossRef]

30. Kudryasheva, N.; Vetrova, E.; Kuznetsov, A.; Kratasyuk, V.; Stom, D. Bioluminescence Assays: Effects of Quinones and Phenols. Ecotoxicol. Environ. Saf. 2002, 53, 221-225. [CrossRef]

31. Kratasyuk, V.A. Principle of luciferase biotesting. Biol. Lumin. 1990, 660.

32. Esimbekova, E.N.; Torgashina, I.G.; Kalyabina, V.P. Enzymatic Biotesting: Scientific Basis and Application. Contemp. Probl. Ecol. 2021, 14, 290-304. [CrossRef]

33. Esimbekova, E.N.; Kalyabina, V.P.; Kopylova, K.V.; Torgashina, I.G.; Kratasyuk, V.A. Design of bioluminescent biosensors for assessing contamination of complex matrices. Talanta 2021, 233, 122509. [CrossRef] [PubMed]

34. Lukyanenko, K.A.; Denisov, I.A.; Sorokin, V.V.; Yakimov, A.S.; Esimbekova, E.N.; Belobrov, P.I. Handheld enzymatic luminescent biosensor for rapid detection of heavy metals in water samples. Chemosensors 2019, 7, 16. [CrossRef]

35. Kolosova, E.M.; Sutormin, O.S.; Esimbekova, E.N.; Lonshakova-Mukina, V.I.; Kratasyuk, V.A. Set of enzymatic bioassays for assessment of soil contamination. Dokl. Biol. Sci. 2019, 489, 165-168. [CrossRef]

36. Nemtseva, E.V.; Kudryasheva, N.S. The mechanism of electronic excitation in the bacterial bioluminescent reaction. Russ. Chem. Rev. 2007, 76, 91. [CrossRef]

37. Kudryasheva, N.S. Bioluminescence and exogenous compounds: Physico-chemical basis for bioluminescent assay. J. Photochem. Photobiol. 2006, 83, 77-86. [CrossRef]

38. Rozhko, T.V.; Nemtseva, E.V.; Gardt, M.V.; Raikov, A.V.; Lisitsa, A.E.; Badun, G.A.; Kudryasheva, N.S. Enzymatic Responses to Low-Intensity Radiation of Tritium. Int. J. Mol. Sci. 2020, 21, 8464. [CrossRef]

39. Vetrova, E.V.; Kudryasheva, N.S.; Kratasyuk, V.A. Redox compounds influence on the NAD (P) H: FMN-oxidoreductase-luciferase bioluminescent system. Photochem. Photobiol. Sci. 2006, 6, 35-40. [CrossRef]

40. Rozhko, T.V.; Kudryasheva, N.S.; Kuznetsov, A.M.; Vydryakova, G.A.; Bondareva, L.G.; Bolsunovsky, A.Y. Effect of low-level $\alpha$-radiation on bioluminescent assay systems of various complexity. Photochem. Photobiol. Sci. 2007, 6, 67-70. [CrossRef]

41. Rozhko, T.V.; Kudryasheva, N.S.; Kuznetsov, A.M.; Vydryakova, G.A.; Bondareva, L.G.; Bolsunovsky, A.Y. Comparison of Effects of Uranium and Americium on Bioluminescent Bacteria. J. Sib. Fed. Univ. 2008, 1, 60-65.

42. Kamnev, A.A.; Tugarova, A.V.; Selivanova, M.A.; Tarantilis, P.A.; Polissiou, M.G.; Kudryasheva, N.S. Effects of americium-241 and humic substances on Photobacterium phosphoreum: Bioluminescence and diffuse reflectance FTIR spectroscopic studies. Spectrochim. Acta Part A Mol. Biomol. Spectrosc. 2013, 100, 171-175. [CrossRef] [PubMed]

43. Selivanova, M.A.; Mogilnaya, O.A.; Badun, G.A.; Vydryakova, G.A.; Kuznetsov, A.M.; Kudryasheva, N.S. Effect of tritium on luminous marine bacteria and enzyme reactions. J. Environ. Radioact. 2013, 130, 19-25. [CrossRef] [PubMed]

44. Rozhko, T.V.; Badun, G.A.; Razzhivina, I.A.; Guseynov, O.A.; Guseynova, V.E.; Kudryasheva, N.S. On the mechanism of biological activation by tritium. J. Environ. Radioact. 2016, 157, 131-135. [CrossRef]

45. Rozhko, T.V.; Bondareva, L.G.; Mogilnaya, O.A.; Vydryakova, G.A.; Bolsunovsky, A.Y.; Stom, D.I.; Kudryasheva, N.S. Detoxification of AM-241 Solutions by Humic Substances: Bioluminescent Monitoring. Anal. Bioanal. Chem. 2011, 400, 329-334. [CrossRef]

46. Rozhko, T.V.; Kolesnik, O.V.; Badun, G.A.; Stom, D.I.; Kudryasheva, N.S. Humic Substances Mitigate the Impact of Tritium on Luminous Marine Bacteria. Involvement of Reactive Oxygen Species. Int. J. Mol. Sci. 2020, 21, 6783. [CrossRef]

47. Bondareva, L.; Kudryasheva, N. Direct and Indirect Detoxification Effects of Humic Substances. Agronomy 2021, 11, 198. [CrossRef]

48. Kudryasheva, N.S.; Tarasova, A.S. Pollutant toxicity and detoxification by humic substances: Mechanisms and quantitative assessment via luminescent biomonitoring. Environ. Sci. Pollut. Res. 2015, 22, 155-167. [CrossRef]

49. Sachkova, A.S.; Kovel, E.S.; Churilov, G.N.; Stom, D.I.; Kudryasheva, N.S. Biological activity of carbonic nano-structures. Comparison via enzymatic bioassay. J. Soils Sediments 2019, 19, 2689-2696. [CrossRef]

50. Kudryasheva, N.S.; Rozhko, T.V. Effect of low-dose ionizing radiation on luminous marine bacteria: Radiation hormesis and toxicity. J. Environ. Radioact. 2015, 142, 68-77. [CrossRef]

51. Calabrese, E. Hormesis: Path and Progression to Significance. Int. J. Mol. Sci. 2018, 19, 2871. [CrossRef] [PubMed]

52. Jargin, S.V. Hormesis and Radiation Safety Norms: Comments for an Update. Hum. Exp. Toxicol. 2018, 37, 1233-1243. [CrossRef] [PubMed] 
53. Shibamoto, Y.; Nakamura, H. Overview of Biological, Epidemiological, and Clinical Evidence of Radiation Hormesis. Int. J. Mol. Sci. 2018, 19, 2387. [CrossRef] [PubMed]

54. Ge, H.; Zhou, M.; Lv, D.; Wang, M.; Xie, D.; Yang, X.; Dong, C.; Li, S.; Lin, P. Novel Segmented Concentration Addition Method to Predict Mixture Hormesis of Chlortetracycline Hydrochloride and Oxytetracycline Hydrochloride to Aliivibrio Fischeri. Int. J. Mol. Sci. 2020, 21, 481. [CrossRef]

55. Kovel, E.S.; Sachkova, A.S.; Vnukova, N.G.; Churilov, G.N.; Knyazeva, E.M.; Kudryasheva, N.S. Antioxidant Activity and Toxicity of Fullerenols via Bioluminescence Signaling: Role of Oxygen Substituents. Int. J. Mol. Sci. 2019, 20, 2324. [CrossRef]

56. Kovel, E.S.; Kicheeva, A.G.; Vnukova, N.G.; Churilov, G.N.; Stepin, E.A.; Kudryasheva, N.S. Toxicity and Antioxidant Activity of Fullerenol C60,70 with Low Number of Oxygen Substituents. Int. J. Mol. Sci. 2021, 22, 6382. [CrossRef]

57. Bondarenko, L.S.; Kovel, E.S.; Kydralieva, K.A.; Dzhardimalieva, G.I.; Illés, E.; Tombácz, E.; Kicheeva, A.G.; Kudryasheva, N.S. Effects of Modified Magnetite Nanoparticles on Bacterial Cells and Enzyme Reactions. Nanomaterials 2020, 10, 1499. [CrossRef]

58. Stolyar, S.V.; Kolenchukova, O.A.; Boldyreva, A.V.; Kudryasheva, N.S.; Gerasimova, Y.V.; Krasikov, A.A.; Yaroslavtsev, R.N.; Bayukov, O.A.; Ladygina, V.P.; Birukova, E.A. Biogenic Ferrihydrite Nanoparticles: Synthesis, Properties In Vitro and In Vivo Testing and the Concentration Effect. Biomedicines 2021, 9, 323. [CrossRef]

59. Khan, P.; Idrees, D.; Moxley, M.A.; Corbett, J.A.; Ahmad, F.; von Figura, G.; Sly, W.S.; Waheed, A.; Hassan, M.I. Luminol-Based Chemiluminescent Signals: Clinical and Non-Clinical Application and Future Uses. Appl. Biochem. Biotechnol. 2014, 173, 333-355. [CrossRef]

60. Vasil'ev, R.F.; Veprintsev, T.L.; Dolmatova, L.S.; Naumov, V.V.; Trofimov, A.V.; Tsaplev, Y.B. Kinetics of Ethylbenzene OxyChemiluminescence in the Presence of Antioxidants from Tissues of the Marine Invertebrate Eupentacta Fraudatrix: Es-timating the Concentration and Reactivity of the Natural Antioxidants. Kinet. Catal. 2014, 55, 148-153. [CrossRef]

61. Venzhik, Y.V.; Moshkov, I.E.; Dykman, L.A. Gold nanoparticles in plant physiology: Principal effects and prospects of application. Russ. J. Plant Physiol. 2021, 68, 401-412. [CrossRef]

62. Dykman, L.A.; Khlebtsov, N.G. Methods for chemical synthesis of colloidal gold. Russ. Chem. Rev. 2019, 88, 229-247. [CrossRef]

63. Aldewachi, H.; Chalati, T.; Woodroofe, M.N.; Bricklebank, N.; Sharrack, B.; Gardiner, P. Gold nanoparticle-based colorimetric biosensors. Nanoscale 2018, 10, 18-33. [CrossRef] [PubMed]

64. Kamnev, A.A. Infrared spectroscopy in studying biofunctionalised gold nanoparticles. In Nanomaterials Imaging Techniques, Surface Studies, and Applications (Springer Proceedings in Physics, Vol. 146); Fesenko, O., Yatsenko, L., Brodin, M., Eds.; Springer: New York, NY, USA, 2013; Volume 3, pp. 35-50. [CrossRef]

65. Kuznetsov, A.M.; Rodicheva, E.K.; Shilova, E. V Bioassay Based on Lyophilized Bacteria. Biotekhnologiya 1996, 9, $57-61$.

66. Barbosa, S.; Agrawal, A.; Rodríguez-Lorenzo, L.; Pastoriza-Santos, I.; Alvarez-Puebla, R.A.; Kornowski, A.; Weller, H.; Liz-Marzán, L.M. Tuning size and sensing properties in colloidal gold nanostars. Langmuir 2010, 26, 14943-51490. [CrossRef]

67. Fedorova, E.; Kudryasheva, N.; Kuznetsov, A.; Mogil'naya, O.; Stom, D. Bioluminescent monitoring of detoxification processes: Activity of humic substances in quinone solutions. J. Photochem. Photobiol. 2007, 88, 131-136. [CrossRef]

68. Shabanova, O.V.; Nemtsev, I.V.; Shabanov, A.V. Development of SEM method for analysis of organ-containing objects using inverse opals. Sib. J. Sci. Technol. 2020, 21, 565-573. [CrossRef]

69. Kabe, D. Fundamentals of Probability Theory and Mathematical Statistics. Can. Math. Bull. 1970, 13, 398-399. [CrossRef]

70. Drozdov, A.V.; Gromozova, E.N.; Gretsky, I.A. An analysis of the bioluminescence intensity dynamics of the luminous bacteria Photobacterium phosphoreum. Biophysics 2015, 60, 251-255. [CrossRef]

71. Kuts, V.V.; Ismailov, A.D. Physiological and emission characteristics of the luminescent bacterium Photobacterium Phosphoreum from the White Sea. Microbiology 2009, 78, 554. [CrossRef]

72. Davis, J.M.; Svendsgaard, D.J. U-Shaped dose-response curves: Their occurrence and implications for risk assessment. J. Toxicol. Environ. Health 1990, 30, 71-83. [CrossRef] [PubMed]

73. Calabrese, E.J.; Baldwin, L.A. The frequency of U-shaped dose responses in the toxicological literature. Toxicol. Sci. 2001, 62, 330-338. [CrossRef]

74. Kaiser, J. Hormesis: Sipping from a poisoned chalice. Science 2003, 302, 376-379. [CrossRef] [PubMed]

75. Calabrese, E.J. Hormetic mechanisms. Crit. Rev. Toxicol. 2013, 43, 580-606. [CrossRef] [PubMed]

76. Kempson, I. Mechanisms of nanoparticle radiosensitization. WIREs Nanomed. Nanobiotechnol. 2021, 13, 1656. [CrossRef]

77. Kunz-Schughart, L.A.; Dubrovska, A.; Peitzsch, C.; Ewe, A.; Aigner, A.; Schellenburg, S.; Muders, M.H.; Hampel, S.; Cirillo, G.; Iemma, F. Nanoparticles for radiooncology: Mission, vision, challenges. Biomaterials 2017, 120, 155-184. [CrossRef]

78. Peukert, D.; Kempson, I.; Douglass, M.; Bezak, E. Metallic nanoparticle radiosensitisation of ion radiotherapy: A review. Phys. Med. 2018, 47, 121-128. [CrossRef]

79. Liu, Y.; Zhang, P.; Li, F.; Jin, X.; Li, J.; Chen, W.; Li, Q. Metal-based NanoEnhancers for Future Radiotherapy: Radiosensitizing and Synergistic Effects on Tumor Cells. Thernostics 2018, 8, 1824-1849. [CrossRef]

80. Vilotte, F.; Jumeau, R.; Bourhis, J. High Z nanoparticles and radiotherapy: A critical view. Lancet Oncol. 2019, 20, 557. [CrossRef]

81. Howard, D.; Sebastian, S.; Le, Q.V.-C.; Thierry, B.; Kempson, I. Chemical Mechanisms of Nanoparticle Radiosensitization and Radioprotection: A Review of Structure-Function Relationships Influencing Reactive Oxygen Species. Int. J. Mol. Sci. 2020, 21, 579. [CrossRef] 
82. Gilles, M.B.; Brun, E.; Sicard-Roselli, C. Quantification of hydroxyl radicals and solvated electrons produced by irradiated gold nanoparticles suggests a crucial role of interfacial water. J. Colloid Interface Sci. 2018, 525, 31-38. [CrossRef] [PubMed]

83. Nikolaos, M.; Dimitriou, G.T.; Evangelos, C.; Balanikas, E.; Pavlopoulou, A.; Mitsiogianni, M.; Mantso, T.; Pashos, G.; Boudouvis, A.G.; Lykakis, I.N. Gold nanoparticles, radiations and the immune system: Current insights into the physical mechanisms and the biological interactions of this new alliance towards cancer therapy. Pharmacol. Ther. 2017, 178, 1-17. [CrossRef]

84. Liu, R. Adsorption and dissociation of $\mathrm{H}_{2} \mathrm{O}$ on $\mathrm{Au}$ (111) surface: A DFT study. Comput. Theor. Chem. 2013, 1019, 141-145. [CrossRef]

85. Li, Q. Effect of Surface Coating of Gold Nanoparticles on Cytotoxicity and Cell Cycle Progression. Nanomaterials 2018, 8, 1063. [CrossRef] [PubMed]

86. Chatterjee, S.; Bandyopadhyay, A.; Sarkar, K. Effect of iron oxide and gold nanoparticles on bacterial growth leading towards biological application. J. Nanobiotechnol. 2011, 9, 34. [CrossRef] [PubMed]

87. Truong, L.B.; Medina-Cruz, D.; Mostafavi, E.; Rabiee, N. Selenium nanomaterials to combat antimicrobial resistance. Molecules 2021, 26, 3611. [CrossRef]

88. Ojeda, J.J.; Merroun, M.L.; Tugarova, A.V.; Lampis, S.; Kamnev, A.A.; Gardiner, P.H.E. Developments in the study and applications of microbial transformations of selenium species. Crit. Rev. Biotechnol. 2020, 40, 1250-1264. [CrossRef]

89. Tugarova, A.V.; Kamnev, A.A. Proteins in microbial synthesis of selenium nanoparticles. Talanta 2017, 174, 539-547. [CrossRef]

90. Kamnev, A.A.; Dyatlova, Y.u.A.; Kenzhegulov, O.A.; Vladimirova, A.A.; Mamchenkova, P.V.; Tugarova, A.V. Fourier transform infrared (FTIR) spectroscopic analyses of microbiological samples and biogenic selenium nanoparticles of microbial origin: Sample preparation effects. Molecules 2021, 26, 1146. [CrossRef]

91. Tugarova, A.V.; Mamchenkova, P.V.; Khanadeev, V.A.; Kamnev, A.A. Selenite reduction by the rhizobacterium Azospirillum brasilense, synthesis of extracellular selenium nanoparticles and their characterisation. New Biotechnol. 2020, 58, 17-24. [CrossRef] 